\title{
Rising epidemic of HIV-1 infections among general populations in Fujian, China
}

\author{
H Wang ${ }^{1 *}, X$ Yao $^{2}, \mathrm{P} \mathrm{Yan}^{3}, \mathrm{Z}$ Chen $^{1}$ \\ From AIDS Vaccine 2012 \\ Boston, MA, USA. 9-12 September 2012
}

\section{Background}

Monitoring HIV transmission and viral diversity has significant impacts on guiding effective vaccine development. Until now, few large-scale studies have investigated HIV infections among the general populations of China.

\section{Methods}

915,830 and 2,152,658 blood samples from various groups were collected in 2006-2007 and 2008-2009, respectively, in Fujian, a low prevalent region in China. Comprehensive HIV-1 epidemiology and molecular epidemiology studies were conducted.

\section{Results}

Our data revealed a significant rise of the overall prevalence of infections within a short time period, from $0.064 \%$ in $2006-2007$ to $0.074 \%$ in $2008-2009$ ( $\mathrm{p}=0.003$ ), which resulted in the double numbers of infections from 528 in 2006-2007 to 1129 in 2008-2009. Critically, the prevalence rate among general populations such as voluntary blood donors, recipients of blood transfusion and people during pre-surgery screening had significantly increased in recent years $(\mathrm{p}<0.001)$. Besides CRF01_AE as the dominant circulating subtype (61/86, 70.9\%), 25 nonCRF01_AE strains were found contributing to increased HIV-1 genetic diversity including C/CRF07_BC/ CRF08_BC (5.8\%), B/B' (15.1\%) and unique recombinant forms $(8.1 \%)$. More than $30 \%(26 / 81)$ of subjects were found to contain various drug-resistant mutations.

\section{Conclusion}

The rising epidemic in recent years in Fujian is likely due to the increased prevalence of HIV-1 infections among general populations and multiple viral subtypes circulating.

${ }^{1}$ AIDS Institute, LKS Faculty of Medicine, The University of Hong Kong, Hong Kong, Hong Kong

Full list of author information is available at the end of the article
Our findings will be useful for helping to enhance the current surveillance system and to generate strategic prevention programs targeting general populations in China. Moreover, these results also have implications for AIDS vaccine research.

\section{Author details}

${ }^{1}$ AIDS Institute, LKS Faculty of Medicine, The University of Hong Kong, Hong Kong, Hong Kong. Fuzhou Center for Disease Control and Prevention, Fuzhou, China. ${ }^{3}$ Fujian Center for Disease Control and Prevention, Fuzhou, China.

Published: 13 September 2012

\section{doi:10.1186/1742-4690-9-S2-P138}

Cite this article as: Wang et al:: Rising epidemic of HIV-1 infections among general populations in Fujian, China. Retrovirology 2012 9(Suppl 2):P138.
Submit your next manuscript to BioMed Central and take full advantage of:

- Convenient online submission

- Thorough peer review

- No space constraints or color figure charges

- Immediate publication on acceptance

- Inclusion in PubMed, CAS, Scopus and Google Scholar

- Research which is freely available for redistribution
C Biomed Central

\section{Biomed Central}

(c) 2012 Wang et al; licensee BioMed Central Ltd. This is an Open Access article distributed under the terms of the Creative Commons Attribution License (http://creativecommons.org/licenses/by/2.0), which permits unrestricted use, distribution, and reproduction in any medium, provided the original work is properly cited. 